\title{
Assessment of Emergency Service Attendance Due to Rabies Suspect Animal Bites in the Van Region
}

\author{
(1) Behçet Varıșlı1, (1) Sinan Yıldırım¹, (1) Hamit Çelik², (1) Mehtap Bulut ${ }^{3}$, (1) Özgül Ocak \\ ${ }^{1}$ Clinic of Emergency Medicine, Çanakkale Mehmet Akif Ersoy State Hospital, Çanakkale, Turkey \\ ${ }^{2}$ Clinic of Neurology, Private Buhara Hospital, Erzurum, Turkey \\ ${ }^{3}$ Clinic of Emergency Medicine, İstanbul Medipol University Hospital, İstanbul, Turkey \\ ${ }^{4}$ Department of Neurology, Çanakkale Onsekiz Mart University Faculty of Medicine, Çanakkale, Turkey
}

\begin{abstract}
Aim: Rabies is a zoonotic viral disease transmitted by the bite of an animal. In Turkey, 100,000 individuals are administered prophylaxis annually after contact with animals carrying the risk of rabies. In this study, we investigated compliance with treatment and the affecting factors.

Materials and Methods: The study assessed data from a total of 813 patients with potential animal bites throughout the year 2013.

Results: The mean age of participants in the study was $22.6 \pm 16.8$ years, and $80.6 \%(n=655)$ were male. Participants of both sexes mainly attended in the spring and summer months; however, it was identified that the rate of women attending in winter was higher than men. Also, five doses of vaccination were ordered for nearly all patients, independent of immunoglobulin administration; however, the rate of patients completing all five doses remained at about $30 \%$.

Conclusion: Increasing awareness of rabies will aid in the control of the significant public health problem of potential bite cases. As the young population is at risk, it is necessary to take precautions for the childhood age group.
\end{abstract}

Keywords: Emergency service, rabies, animal bites

\section{Introduction}

Rabies disease is a zoonotic viral disease transmitted by bites from an animal with rabies. The rabies virus is a bullet-shaped, single-chain, negative-strand RNA virus from the Rhabdoviridae family. Clinical symptoms progress with acute encephalitis, causing mortality in humans and animals $(1,2)$. According to the 2010 World Health Organization (WHO) data, it is reported in more than 150 countries. The most important source of transmission to humans is the animals living in close surroundings. Some carnivores and bats are natural reservoirs, but 99\% of transmission to humans occurs via dogs $(3,4)$.
Deaths linked to rabies in many countries are not reported, especially in the young age group (4). Additionally, a significant portion of the 55,000 annual deaths occurs in Africa and Asia. It is observed in every age group, but children under the age of 15 years are the at-risk group. Of vaccinations linked to potential bites from rabid animals, 40\% are administered to the 5-14-year age group. It is known that the male gender is dominant in the vaccinated population (5). Beginning with fever and frequently pain and paresthesia around the wound, rabies disease develops with encephalitis progressing to mortality after the virus spread through the central nervous system. Within a few days, death is observed after cardiovascular arrest $(4,6,7)$. Rabies disease with paralytic progression is less dramatic and lasts longer, but 
mostly results in death. Paralytic rabies disease is frequently not reported due to a lack of diagnosis (4).

As there is no effective treatment for rabies, prophylaxis after contact is very important (8). Prophylaxis with vaccinations prepared in modern tissue and rabies immunoglobulin (RIG) after contact with rabies ensures close to $100 \%$ success with accurate dose administration at the right time. WHO has a broad spectrum concerning prophylaxis after contact, including the Essen regimen. The Essen regime recommends intramuscular administration of 5 doses of human diploid cell rabies vaccine (on days $0,3,7,14,28$ ) in addition to RIG. The Center for Disease Control (CDC) in 2009 did not include the dose on the $28^{\text {th }}$ day in the regime and modified it to four doses and RIG. There are studies showing compliance to four-dose treatment is better than compliance with five-dose treatment (9-11). In the literature, after the first administration, compliance appears to reduce linked to factors such as forgetting, missing or neglecting, patient's health status, age, and gender (12-15).

Vaccinations produced from cell cultures and produced from embryo egg cell cultures are used around the world. Apart from the vaccine, there are two types of RIG used for rabies prophylaxis; the human RIG (HRIG) with a recommended dose of $20 \mathrm{IU} / \mathrm{kg}$ and the RIG (ERIG) used at $40 \mathrm{IU} / \mathrm{kg}$ dose. According to the recent recommendations of WHO and CDC, if the wound is anatomically suitable, the full dose RIG should be administered around the wound (16).

Together with a reducing trend in human cases through the years, animal cases continue to represent a significant problem. In Turkey, 100,000 people are administered prophylaxis annually after contact with animals at risk of rabies (17). Rabies prophylaxis is completed following the Rabies Protection and Control Regulation by the Ministry of Health General Directorate of Primary Health Care. Rabies vaccines and RIG are acquired under state authority.

Monthly mean 70-80 and annually 800-900 cases attend our clinic with potential animal bites. $98 \%$ of them received immediate prophylaxis. Due to the high mortality of rabies disease, the number of individuals receiving prophylaxis may be higher than necessary. As a result, this is significant for the efficacy of the vaccine and side effects. Currently, the side effects linked to the vaccine are less severe and very rare, varying according to the origin of the vaccine (18-22).

The necessity for regular administration of the prophylaxis regime and the side effects of the vaccine affect individual compliance. In this study, the compliance and factors affecting the compliance of patients receiving prophylaxis after attending our clinic with a preliminary diagnosis of potential rabid animal bites were investigated.

\section{Materials and Methods}

The study was completed with information obtained from patients attending the emergency service of an education and research hospital in the Van region from 01.01.2013 to 31.12.2013. The study assessed data from a total of 813 patients. The type of contact (bite, scratch, splash in the mucous membranes, etc.) and the condition of the animal (breed, vaccination status, etc.) are taken into consideration.

\section{Statistical Analysis}

Statistical analyses used the SPSS version 15 software. Statistical significance was accepted as $p<0.05$. Descriptive statistics such as age were given as mean \pm standard deviation. Categorical variables, such as gender, planned dose of vaccine, the dose of vaccine administered, immunoglobulin administration, etc. were given as numbers and percentages.

\section{Results}

Our study assessed the data from a total of 813 patients, $80.6 \%$ male $(n=655)$ and $19.4 \%$ female $(n=158)$. The demographic data and treatment characteristics of participants in the study are summarized in Table 1.

The differences between the sexes in terms of demographic characteristics and clinical parameters are summarized in Table 2. Accordingly, participants of both sexes mainly attended in spring and summer; however, it is notable that the proportion of females attending in winter was elevated compared to males. There was no statistically significant difference observed among participants in terms of residential areas and planned and administered vaccine doses.

The distribution of planned and administered vaccine doses according to immunoglobulin administration is shown in Table 3 for study participants. As suggested by the Essen regime, five doses of vaccination were planned for nearly all of the patients, independent of immunoglobulin administration; however, only $30 \%$ of patients completed all five doses.

\section{Discussion}

Rabies is one of the zoonotic diseases progressing with mortality that threatens the whole world $(23,24)$. Rabies is a serious health problem, especially in developing countries like Turkey. Despite reductions in frequency due to the Ministry of Health vaccination and prophylaxis protocols, it is still an important disease vector in regions with low socioeconomic status and in provinces with 
Table 1. Demographic and clinical characteristics of the study group

\begin{tabular}{|c|c|c|c|}
\hline & & Mean & SD \\
\hline Age mean \pm SD & & $\mathrm{n}(22.6)$ & $(16.8) \%$ \\
\hline \multirow{2}{*}{ Sex } & Male & 655 & 80.6 \\
\hline & Female & 158 & 19.4 \\
\hline \multirow{2}{*}{ Residence } & Center & 455 & 56.5 \\
\hline & Periphery & 350 & 43.5 \\
\hline \multirow{12}{*}{ Month of attendance } & January & 70 & 8.6 \\
\hline & February & 65 & 8.0 \\
\hline & March & 58 & 7.1 \\
\hline & April & 53 & 6.5 \\
\hline & May & 83 & 10.2 \\
\hline & June & 96 & 11.8 \\
\hline & July & 103 & 12.7 \\
\hline & August & 84 & 10.3 \\
\hline & September & 71 & 8.7 \\
\hline & October & 53 & 6.5 \\
\hline & November & 34 & 4.2 \\
\hline & December & 43 & 5.3 \\
\hline \multirow{2}{*}{$\begin{array}{l}\text { Immunoglobulin } \\
\text { administration }\end{array}$} & Yes & 495 & 61.2 \\
\hline & No & 314 & 38.8 \\
\hline \multirow{4}{*}{ Planned vaccination dose } & 1 dose & 1 & 0.1 \\
\hline & 2 dose & 1 & 0.1 \\
\hline & 4 dose & 6 & 0.7 \\
\hline & 5 dose & 804 & 99.0 \\
\hline \multirow{5}{*}{ Dose administered } & 1 dose & 76 & 9.4 \\
\hline & 2 doses & 87 & 10.7 \\
\hline & 3 doses & 204 & 25.2 \\
\hline & 4 doses & 173 & 21.3 \\
\hline & 5 doses & 271 & 33.4 \\
\hline
\end{tabular}

SD: Standard deviation

intense animal husbandry. Due to the disease being a significant public health problem, primary protection is essential. Animals suspected of having rabies should be removed from the environment, and individuals living in risky regions should be informed about this topic. Primary protection is not always sufficient for rabies disease. Vaccination after contact is crucial.

In our study assessing the rabies prophylaxis regime and treatment compliance of patients attending our clinic with suspect animal bites and rabies suspicion, data from 813 patients were investigated. The mean age of patients beginning treatment was $22.6 \pm 16.8$ years. Of the cases in our study, $39.1 \%$ were aged 11 years or younger, and $54.4 \%$ were aged 18 years and older. Another study investigating patients attending the emergency service found that $54 \%$ of patients were aged 18 or younger (25).
Table 2. Distribution of demographic and clinical characteristics of the study group according to sex

\begin{tabular}{|c|c|c|c|c|}
\hline \multirow{2}{*}{ Mean (SD) } & & Male & Female & $p$ \\
\hline & & \multicolumn{2}{|l|}{ Mean (SD) } & \\
\hline AGE mean \pm SD & & $21.7(15.7)$ & $26.1(20.5)$ & 0.232 \\
\hline \multirow{2}{*}{ Residence } & Center & $363(56.1)$ & $92(58.2)$ & \multirow{2}{*}{0.629} \\
\hline & Periphery & $284(43.9)$ & $66(41.8)$ & \\
\hline \multirow{12}{*}{$\begin{array}{l}\text { Month of } \\
\text { attendance }\end{array}$} & January & $62(9.5)$ & $8(5.1)$ & \multirow{12}{*}{0.02} \\
\hline & February & $44(6.7)$ & $21(13.3)$ & \\
\hline & March & $50(7.6)$ & $8(5.1)$ & \\
\hline & April & $41(6.3)$ & $12(7.6)$ & \\
\hline & May & $59(9.0)$ & $24(15.2)$ & \\
\hline & June & $74(11.3)$ & $22(13.9)$ & \\
\hline & July & $83(12.7)$ & $20(12.7)$ & \\
\hline & August & $70(10.7)$ & $14(8.9)$ & \\
\hline & September & $59(9.0)$ & $12(7.6)$ & \\
\hline & October & $49(7.5)$ & $4(2.5)$ & \\
\hline & November & $28(4.3)$ & $6(3.8)$ & \\
\hline & December & $36(5.5)$ & $7(4.4)$ & \\
\hline \multirow{2}{*}{$\begin{array}{l}\text { Immunoglobulin } \\
\text { administration }\end{array}$} & Yes & 401 (61.6) & $94(59.5)$ & \multirow{2}{*}{0.626} \\
\hline & No & $250(38.4)$ & $64(40.5)$ & \\
\hline \multirow{4}{*}{$\begin{array}{l}\text { Planned } \\
\text { vaccination dose }\end{array}$} & 1 dose & - & $1(0.6)$ & \\
\hline & 2 dose & - & $1(0.6)$ & \\
\hline & 4 dose & $3(0.5)$ & $3(1.9)$ & \\
\hline & 5 dose & 651 (99.5) & $153(96.8)$ & \\
\hline \multirow{5}{*}{$\begin{array}{l}\text { Dose } \\
\text { administered }\end{array}$} & 1 dose & $64(9.8)$ & $12(7.6)$ & \multirow{5}{*}{0.246} \\
\hline & 2 doses & $76(11.6)$ & $11(7.0)$ & \\
\hline & 3 doses & $157(24.0)$ & $47(29.9)$ & \\
\hline & 4 doses & $142(21.7)$ & 31 (19.7) & \\
\hline & 5 doses & 215 (32.9) & $56(35.7)$ & \\
\hline
\end{tabular}

Table 3. Distribution of vaccination administration according to immunoglobulin administration

\begin{tabular}{|c|c|c|c|c|c|}
\hline \multirow[t]{2}{*}{$\mathbf{n}$} & & \multicolumn{2}{|c|}{$\begin{array}{l}\text { Immunoglobulin } \\
(+)\end{array}$} & \multirow{2}{*}{\multicolumn{2}{|c|}{$\begin{array}{l}\text { Immunoglobulin } \\
(-) \\
\%\end{array}$}} \\
\hline & & $\%$ & $\mathrm{n}$ & & \\
\hline \multirow{4}{*}{$\begin{array}{l}\text { Planned } \\
\text { vaccination } \\
\text { dose }\end{array}$} & 1 dose & 1 & 0.2 & - & - \\
\hline & 2 dose & - & - & 1 & 0.3 \\
\hline & 4 dose & 1 & 0.2 & 5 & 1.6 \\
\hline & 5 dose & 493 & 99.6 & 307 & 98.1 \\
\hline \multirow{5}{*}{$\begin{array}{l}\text { Dose } \\
\text { administered }\end{array}$} & 1 dose & 45 & 9.1 & 31 & 9.9 \\
\hline & 2 doses & 46 & 9.3 & 41 & 13.1 \\
\hline & 3 doses & 125 & 25.3 & 79 & 25.3 \\
\hline & 4 doses & 111 & 22.4 & 62 & 19.9 \\
\hline & 5 doses & 168 & 33.9 & 99 & 31.7 \\
\hline
\end{tabular}


As seen in studies, the young age group is at risk of this disease, but there was no correlation identified with age. Additionally, attendance in the first 24-48 hours after contact with the disease is considered to be effective in reducing mortality that may occur due to rabies.

Most of the patients attending with suspect animal bites were male. Males are involved more in agriculture and animal husbandry and spend a long time outside compared to females, which may have increased their chances of encountering danger. In the literature, it is reported that rural contact is less compared to urban contact. More than half of our cases (56.1\%) attended from the city center. The study by Temiz and Akkoç (26) identified lower attendance from rural areas. Again, a study by Tunç et al. (25) found that attendance from urban areas was more common. One reason for frequent attendance from the city center may be that access is easier. Also, it may be due to the control of stray animals being harder in urban areas.

Again, another reason may be that awareness about attending a vaccination center for rabies is not at sufficient levels among those living in rural areas (27).

Generally, rabies cases intensify in spring and summer. This period is known as the aggressive period for dogs. Due to wearing thinner clothes and spending more time outdoor, animal bites increase in summer. The study identified that the potential animal bite cases increased in spring and summer when individuals spend more time outside. Nearly half of the cases (50.7\%) were in the period from April to August. In the literature, there is not much information about seasonal variations in rabies disease. Also, females had higher potential rabid animal bites in winter compared to males ( $p=0.02$ ); however, this is not an expected result. Studies to be performed must consider the periodic effects on disease control.

In developing countries, rabies is transmitted to humans by bites from stray animals, especially dogs. In cases, attention is paid to dogs, especially, but also cats and other domestic animals, bats, and other wild animals (28). In our study, the distribution of potential rabies bites was not investigated, but it is considered that the incidence of dog bites was high. For transmission of rabies, direct contact with infected saliva in some situations involving biting, scratching, and licking is the most important route. Most of the cases identified in the study had a history of bites. An assessment by Yılmaz et al. (29) observed that more than half of the cases (56.1\%) had a history of bites. Most of the cases, having a history of bites and being from the city center lead to consideration that local administrations do not have sufficient success in controlling rabies. Again, the insufficient number of stray animal shelters in Van city center may be an important cause.
The contact region of potential rabies bite varies according to the age and physical features of the person. The most common injured region in the literature appears to be the extremities. This information was not collected in the study; however, it was observed that the extremities were most commonly injured clinically, especially at a young age $(29,30)$.

Globally, it is known that between ten and twelve million cases have prophylaxis after rabies contact. In Turkey, there is a reduction observed in human rabies cases, but the suspect bite cases have not reduced. Annually, our country administers prophylaxis to 100,000 bite cases. The rabies risk contact incidence was 211.35 per hundred thousand in 2005 (27). In the early period, local wound care and washing the wound with water and soap are the most effective treatment methods (31). In our clinic, immunization was planned after washing the patients' wounds. Doses were planned as follows; $0.1 \% 1$ dose, $0.1 \% 2$ doses, $0.7 \% 4$ doses and $99.0 \% 5$ doses. The incidence of 5 dose vaccination plans was $99.5 \%$ for male patients and 96.8\% for female patients. In cases where animal monitoring could be performed, three-dose vaccination is sufficient, while five doses were planned for cases without animal monitoring. Vaccine, along with rabies HRIG administration, is life-saving (32). Of cases, $61.2 \%$ had HRIG administered. Rabies studies have observed that RIG administration is not at desired levels $(27,29)$. Cases in Turkey were identified to have higher levels of immunoglobulin administered; however, it was not observed to be at sufficient levels.

There was no information collected related to whether animals had owners in the cases, which led to all cases requiring vaccination. Prophylaxis vaccination is mandatory due to not knowing whether animals are vaccinated or not. This is a public health problem and is encountered with a different dimension in the country's economy. Of cases, $99.0 \%$ had five-dose vaccination planned; however, $33.4 \%$ fully completed the five doses. The planned (96.8\%) and administered (35.7\%) incidence was higher among females, while fewer were administered (32.9\%) for males $(p=0.246)$. In developed countries, vaccination planning is done according to case circumstances. A study in the United States of America concluded that vaccination was required for only $6.7 \%$ of cases (33). Surveillance and monitoring are found to be primary paths for the management of potential rabies bite cases. In the study, $99.6 \%$ of cases with immunoglobulin administered, had five dose vaccination planned, while $33.9 \%$ were vaccinated with five doses. The reason for the difference between planned and administered vaccination doses may be linked to factors such as the administration method of the vaccine, side effects linked to the vaccine, forgetting administration, missing or not attending appointments, patient health status, age, and gender (12-15). 
There were no side effects linked to the vaccine observed in our study. Again, in the study period, there were no deaths linked to potential rabid animal bites.

\section{Conclusion}

One of the most effective solutions for reducing the risk of rabies contact is taking control of stray animals in animal shelters. In these places, street cats and dogs are collected, cared for, and vaccinated, which may ensure primary protection by performing animal fostering and neutering studies. Increasing awareness of this type of application and service, which is among municipality responsibilities, will aid in the control of the significant public health problem of potential rabies bite cases. As the young population is at most risk, the necessity to take precautions among the childhood age group was noted.

\section{Ethics}

Ethics Committee Approval: Çanakkale Onsekiz Mart University Clinical Research Ethics Committee (approval number: 02.01.2019/01-02)

Informed Consent: Consent form was filled out by all participants.

Peer-review: Externally and internally peer-reviewed.

\section{Authorship Contributions}

Surgical and Medical Practices: B.V., Concept: B.V., H.C,., M.B., Design: S.Y., M.B., Data Collection or Processing: B.V., Ö.O., Analysis or Interpretation: S.Y., H.Ç., Literature Search: B.V., H.Ç., M.B., Ö.O., Writing: B.V., M.B.

Conflict of Interest: No conflict of interest was declared by the authors.

Financial Disclosure: The authors declared that this study received no financial support.

\section{References}

1. World Health Organisation. Rabies: a neglected zoonotic disease [cited 2014 May]. Available from: http://www.who.int/rabies/en/.

2. Koruk ST, Koruk I, Kutlu S. Where Do We Stand in the Control of Rabies? Knowledge and Practices Among Physicians in a Health District in Turkey. Wilderness Environ Med. 2011;22:151-5.

3. Rabies vaccines. WHO position paper. Wkly Epidemiol Rec. 2007;82:425-35.

4. Rabies vaccines: WHO position paper. Wkly Epidemiol Rec. 2010;32:309-20.

5. WHO Expert Consultation on Rabies 2004. WHO Technical Report Series. 2004;931:42-55

6. Laothamatas J, Hemachudha T, Mitrabhakdi E, Wannakrairot P, Tulayadaechanont S. MR imaging in human rabies. AJNR Am J Neuroradiol. 2003;24:1102-9

7. Hemachudha T, Wacharapluesadee S, Mitrabhakdi E, Wilde H, Morimoto K, Lewis RA. Pathophysiology of human paralytic rabies. J Neurovirol. 2005; 11:93-100
8. Hanlon C, Carey L. Rabies virus and other rhabdoviruses In: Kasper D, Fauci A, Longo D, editors. Harrison's principles of internal medicine 17th edition ed: McGraw-Hill p. 835.

9. Kieny MP, Quiambao BP, DyTioco HZ, Dizon RM, Crisostomo ME, Laot TM, et al. Rabies Post-Exposure Prophylaxis in the Philippines: Health Status of Patients Having Received Purified Equine $F\left(a b^{\prime}\right) 2$ Fragment Rabies Immunoglobulin (Favirab). PLoS Negl Trop Dis. 2008;2:e243.

10. Tiembre I, Benie J, Attoh-Toure H, Zengbe-Acray P, Tetchi SM, Kpebo D, et al. [Discontinuation of postexposure prophylaxis at the anti-rabies Center of Abidjan, Cote d'Ivoire]. Bull Soc Pathol Exot. 2013;106:272-7.

11. Wiwanitkit V. Missed appointment in rabies vaccination schedule. Arq Neuropsiquiatr. 2012;70:834

12. Rupprecht CE, Briggs D, Brown CM, Franka R, Katz SL, Kerr HD, et al. Use of a reduced (4-dose) vaccine schedule for postexposure prophylaxis to prevent human rabies: recommendations of the advisory committee on immunization practices. MMWR Recomm Rep. 2010;59:1-9.

13. Sudarshan MK, Madhusudana SN, Mahendra BJ, Rao NS, Ashwath Narayana $\mathrm{DH}$, Abdul Rahman $\mathrm{S}$, et al. Assessing the burden of human rabies in India: results of a national multi-center epidemiological survey. Int J Infect Dis. 2007;11:29-35.

14. Sudarshan MK, Narayana DH, Madhusudana SN, Holla R, Ashwin BY, Gangaboraiah B, et al. Evaluation of a one week intradermal regimen for rabies post-exposure prophylaxis: results of a randomized, open label, active-controlled trial in healthy adult volunteers in India. Hum Vaccin Immunother. 2012;8:1077-81.

15. Shantavasinkul P, Tantawichien T, Wilde H, Sawangvaree A, Kumchat A, Ruksaket $\mathrm{N}$, et al. Postexposure rabies prophylaxis completed in 1 week: preliminary study. Clin Infect Dis. 2010;50:56-60.

16. Wilde H, Khawplod P, Hemachudha T, Sitprija V. Postexposure treatment of rabies infection: can it be done without immunoglobulin? Clin Infect Dis. 2002;34:477-80.

17. Tulek N. Rabies virus and other rhabdoviruses infectious. Infectious diseases Istanbul Nobel Medical Bookstores; 2008. p. 673-90.

18. Sampath G, Reddy SV, Rao ML, Rao YU, Palaniappan C. An immunogenicity study of a newly introduced purified Vero cell rabies vaccine (Abhayrab) manufactured in India. Vaccine. 2005;23:897-900.

19. Ashwathnarayana DH, Madhusudana SN, Sampath G, Sathpathy DM, Mankeshwar R, Ravish HH, et al. A comparative study on the safety and immunogenicity of Purified duck embryo vaccine [corrected] (PDEV, Vaxirab) with purified chick embryo cell vaccine (PCEC, Rabipur) and purifed vero cell rabies vaccine (PVRV, Verorab). Vaccine. 2009;28:148-51.

20. Costa WA, Cunha RS, Bolzan VL, Silva Ade C, Caporale GM, Chaves LB, et al. Immunogenicity and safety of a new Vero cell rabies vaccine produced using serum-free medium. Vaccine. 2007;25:8140-5.

21. Seghal S, Bhattacharya D, Bhardwaj M. Five-year longitudinal study of efficacy and safety of purified Vero cell rabies vaccine for post-exposure prophylaxis of rabies in Indian population. J Commun Dis. 1997;29:23-8.

22. Hacibektasoglu A, Inal A, Eyigun C, Barut A, Turkay FA. [Comparison of PVRV and HDCV rabies vaccines as to immunity, reliability and protective value]. Mikrobiyol Bul. 1992;26:26-36.

23. Knobel DL, Cleaveland S, Coleman PG, Fevre EM, Meltzer MI, Miranda ME, et al. Re-evaluating the burden of rabies in Africa and Asia. Bulletin of the World Health Organization. 2005;83:360-8.

24. Cleaveland S, Fevre EM, Kaare M, Coleman PG. Estimating human rabies mortality in the United Republic of Tanzania from dog bite injuries. Bull World Health Organ. 2002;80:304-10.

25. Tunç N, Temiz G, Aras E, Bilgiç A, Onat S. The evaluation of the patients who admitted to a regional hospital emergency service with suspect of rabies. JCEI. 2012;3:383-6. 
26. Temiz H, Akkoç H. Diyarbakır Devlet Hastanesi Kuduz Așı Merkezine Başvuran 809 Olgunun Değerlendirilmesi. Dicle Tıp Dergisi. 2008;35:181-4.

27. Sögüut Ö, Sayhan M, Gokdemir M, Kara H. Türkiye'nin Güneydoğusunda Önlebilir Bir Halk Sağlığı Sorunu: Kuduz Riskli Temas Olguları. Akademik Acil Tıp Dergisi JAEM 2011;1:14-7.

28. Karna G, Kara A. Kuduz; patogenez, tanı ve proflaksi. Hacettepe Tıp Dergisi 2001;32:114-24.

29. Yılmaz F, Akbulut A, Taș M, Kavalcı C, Arslan E, Sönmez M. Kuduz Riskli Hastalarının Değerlendirilmesi. J Clin Anal Med. 2014;5:8-11.
30. Ostanello F, Gherardi A, Caprioli A, La Placa L, Passini A, Prosperi S. Incidence of injuries caused by dogs and cats treated in emergency departments in a major Italian city. Emerg Med J. 2005;22:260-2.

31. World survey of rabies, 1997. Wkly Epidemiol Rec. 1999;74:381-4.

32. Warell M. Rabies. In: Cook G, editor. Manson's Tropical Diseases. 700-20. 20th ed ed. Philadelphia: WB Saunders; 1996.

33. Moran GJ, Talan DA, Mower W, Newdow M, Ong S, Nakase JY, et al. Appropriateness of rabies postexposure prophylaxis treatment for animal exposures. Emergency ID Net Study Group. JAMA. 2000;284:1001-7. 